\title{
Przejawy i przyczyny altruizmu u zwierząt
}

\author{
Manifestations and Causes of Altruism in Animals
}

\author{
Sylwia Niczyporuk1 , Janusz Uchmański² \\ ${ }^{1}$ Centrum Ekologii i Ekofilozofii, Uniwersytet Kardynała Stefana Wyszyńskiego w Warszawie \\ ${ }^{2}$ Instytut Nauk Biologicznych, Uniwersytet Kardynała Stefana Wyszyńskiego w Warszawie \\ ORCID: JU https://orcid.org/0000-0001-8087-8371•j.uchmański@uksw.edu.pl \\ Zgłoszono: 10.03.2021; zrecenzowano: 18.04.2021; zaakceptowano do druku: 21.04.2021
}

\begin{abstract}
Streszczenie: Celem pracy jest przedstawienie ewolucyjnych wyjaśnień współpracy i altruizmu w świecie zwierząt oraz takich form relacji międzygatunkowych, które przynoszą korzyści stronom biorącym w nich udział. Przy wyjaśnianiu posługiwano się pojęciem doboru indywidualnego, doboru grupowego i doboru krewniaczego. W pracy podkreślono istotność relacji wewnątrz - i międzygatunkowych w kształtowaniu obrazu przyrody. Analizując interakcje wewnątrzgatunkowe, skupiono się na wyjaśnieniu tego, jak stopień pokrewieństwa wpływa na relacje pomiędzy krewniakami i jakie są tego skutki w zależności od stopnia pokrewieństwa. Wprowadzono pojęcie doboru krewniaczego, przedstawiono liczne przykłady z tego zakresu oraz wyjaśniono regułę Hamiltona, która w sposób ilościowy ujmuje te zjawiska. Omawiając możliwość nawiązania współpracy między osobnikami niespokrewnionymi tego samego gatunku, wprowadzono pojęcie altruizmu odwzajemnionego i wyjaśniono schemat myślenia zwany dylematem więźnia. Rozważano także możliwe zmiany, jakim w trakcie koewolucji mogą podlegać relacje między gatunkami. W szczególności zastanawiano się, czy koewolucja może prowadzić do wzrostu natężenia pozytywnych relacji między gatunkami aż do przejawów międzygatunkowego altruizmu włącznie. Podano przykłady takiej współpracy, która polega na wzajemnym tworzeniu nisz ekologicznych.
\end{abstract}

Słowa kluczowe: dobór krewniaczy, pokrewieństwo, altruizm, współpraca, altruizm odwzajemniony

\begin{abstract}
The aim of the paper is to provide an evolutionary explanation for co-operation and altruism in the animal world, together with other forms of intra - and inter-species relationships, which bring benefits for both sides involved in it. Concepts of individual selection, group selection, and kin selection were used. The work emphasises the relevance of intra-specific and inter-species relations, in shaping the image of nature. During the analysis of intra-specific interactions, it is explained how the degree of kinship affects the relations between relatives, and what are the results of it, regarding the degree of kinship. The article discusses the notion of kin selection, providing numerous examples in this area. Furthermore, it explains the concept of Hamilton's rule, which covers these phenomena in a quantitative way. Whilst analysing the possibility of co-operation between non-related individuals of the same species, the authors introduce the notion of reciprocal altruism, and explain a particular way of thinking about the above problems, called the 'prisoner's dilemma'. Possible changes that may appear during co-evolution between different species, have also been considered. Examples of co-operation between species that rely on the construction of ecological niches were provided. It has especially been wondered if co-evolution can lead to increased intensity of positive relations between species, up to the manifestations of inter-species altruism inclusive.
\end{abstract}

Keywords: kin selection, kinship, altruism, co-operation, reciprocal altruism 


\section{Wstęp}

Żaden osobnik jakiegokolwiek gatunku nie żyje w izolacji od innych osobników tego samego i innych gatunków (Mackenzie et al. 2015). Liczba i rodzaj interakcji wewnątrz - i międzygatunkowych, jakim podlegają osobniki każdego gatunku, jest ogromna i w każdym konkretnym przypadku trudna do oszacowania. Wpływ tak zwanego środowiska biotycznego - organizmów tego samego i innych gatunków - na przedstawicieli żywego świata jest prawdopodobnie ważniejszą siłą napędzającą biologiczną ewolucję i procesy ekologiczne niż wpływ środowiska nieożywionego. Większość tych wewnątrz - i międzygatunkowych interakcji przynosi straty biorącym w niej stronom. Konkurencja jest szkodliwa dla każdego z konkurentów, ale najczęściej nieunikniona. Bycie ofiarą drapieżnika lub gospodarzem pasożyta to najczęściej śmiertelne zagrożenie dla jednej ze stron tych interakcji. Ale zdarzają się w świecie biologii także sytuacje, gdy osobniki tego samego lub różnych gatunków zachowują się tak, że wszystkie strony biorace udział w tej interakcji odnoszą korzyści. Mamy bowiem przykłady współpracy, a nawet przejawy altruizmu. I nie są to zdarzenia chwilowe ani jednostkowe. Potrafią trwać przez długi czas mierzony w ewolucyjnej skali.

Celem tej pracy jest omówienie tych wewnątrz - i międzygatunkowych interakcji, które kojarzą się nam pozytywnie, i znalezienie uzasadnień tego w kategoriach biologii ewolucyjnej. Będziemy się starali także zastanowić nad tym, w jaką stronę ewoluują te biologiczne interakcje nawet wtedy, gdy na początku nie są to przyjemne relacje dla żadnej lub dla jednej ze stron. Czy jest szansa na to, że częstotliwość pojawiania i utrwalania biologicznych interakcji, które kojarzą się nam pozytywnie, będzie rosła. Jednym słowem, czy świat w miarę upływu biologicznej ewolucji może stawać się coraz lepszy? Odpowiedzi na te pytania będziemy jednak szukali tylko w obrębie współczesnej biologii ewolucyjnej i ekologii.

\section{Rozmnażanie płciowe i bezpłciowe}

Organizmy mogą się rozmnażać płciowo i bezpłciowo. W rozmnażaniu bezpłciowym organizm potomny powstaje bez udziału innego, poza matczynym, osobnika. Potomstwo jest genetycznie identyczne $\mathrm{z}$ organizmem macierzystym. Gdy dochodzi do mutacji, potomstwo będzie genetycznie różne od organizmu macierzystego. Przyczyny mutacji mogą być różne. Większość mutacji jest szkodliwa i obniża zdolność organizmu do przeżycia i wydania potomstwa (Kuzdraliński 2011).

Rozmnażanie bezpłciowe może zachodzić przez podział, pączkowanie lub partenogenezę. Pierwsze z nich jest typowe dla organizmów jednokomórkowych. Wtedy komórka macierzysta dzieli się na dwie komórki potomne. Rozmnażanie przez pączkowanie polega na tym, że wewnątrz organizmu rodzicielskiego rozwija się organizm potomny, który może odłączyć się od swojego rodzica, bądź pozostać z nim w krócej lub dłużej trwającej więzi. W przypadku partenogenezy samica produkuje komórki rozrodcze - jaja. Potomstwo rozwija się z niezapłodnionych jaj, czyli bez udziału plemników pochodzących od samca.

W rozmnażaniu płciowym biorą udział dwa osobniki przeciwnej płci, a organizm potomny powstaje zgodnie $\mathrm{z}$ informacją genetyczną będącą kombinacją materiału genetycznego matki i ojca (Stearns and Hoekstra 2005). Potomstwo jest wtedy genetycznie różne od swoich rodziców, a potomkowie tych samych rodziców będą się również genetycznie różnić między sobą. W przypadku organizmu rozmnażającego się płciowo każda genetycznie uwarunkowana cecha organizmu potomnego jest potencjalnie kodowana przez dwa zestawy genów - jeden pochodzi od matki, drugi od ojca. To, który zestaw genów ulega ekspresji, zależy od ich wzajemnej dominacji. Oznacza to, że potomek jest kombinacją cech matki i ojca. 


\section{Pokrewieństwa}

Niezależnie od tego, w jaki sposób organizmy się rozmnażają, każdy sposób rodzi określone pokrewieństwa. Stopień pokrewieństwa między dwoma osobnikami ma wartość liczbową. Oblicza się ją, patrząc na udział genów w genomie osobnika, które są kopiami genów innego osobnika, z którym szukamy pokrewieństwa. Przy rozmnażaniu bezpłciowym współczynnik pokrewieństwa między matką a jej potomstwem oraz pomiędzy potomstwem jest równy 1 . Rozmnażanie płciowe będzie zaś dawało ułamkowe wartości współczynników pokrewieństwa. W trakcie produkcji jaj lub plemników przez osobnika diploidalnego przekazywane im kopie genów stanowią połowę jego zestawu genów. Tak więc wartość współczynnika pokrewieństwa z jego potomstwem jest równa 0,5. Relacja ta jest symetryczna. Taką samą wartość ma współczynnik pokrewieństwa, jeśli patrzymy od strony potomstwa. Jak z kolei wygląda pokrewieństwo między dziadkami a wnukami? W czasie produkcji komórek płciowych każdy gen z pokolenia dziadków ma prawdopodobieństwo tego, że trafi do pokolenia ich dzieci, równe 0,5 i kolejne prawdopodobieństwo 0,5 , że znajdzie się w pokoleniu ich wnuków. Daje to o, $5^{2}$. Z kolei współczynnik pokrewieństwa między pradziadkami a prawnukami jest równy $0,5^{3}$. Dla pokrewieństw w linii prostej mamy zależność między współczynnikiem pokrewieństwa $r$ a odległością pokoleniową $l$ :

$$
r=0,5^{l}
$$

gdzie $l=1$ dla relacji rodzice-dzieci, 2 dla relacji dziadkowie-wnuki, 3 dla relacji pradziadkowie-prawnuki itd. Podobnie, korzystając ze wzoru przedstawionego powyżej, możemy obliczyć współczynniki pokrewieństwa dla krewnych w linii bocznej (Krebs and Davies 2001).

\section{Dobór krewniaczy}

Konsekwencją różnego stopnia pokrewieństwa między osobnikami jest dobór krewniaczy (Foster et al. 2006). Pojawia się on wtedy, kiedy przychodzi osobnikom żyć $\mathrm{z}$ osobnikami w różnym stopniu $\mathrm{z}$ nimi spokrewnionymi. Jest to zwykły dobór indywidualny, ale działający w specyficznej sytuacji wtedy, kiedy osobniki podlegające doborowi są ze sobą w różnym stopniu spokrewnione.

Podobnie jak zwykły dobór indywidualny, dobór krewniaczy wiąże się ze zróżnicowanym przekazaniem kopii genów przyszłym pokoleniom. Faworyzowane będą przez dobór krewniaczy, podobnie jak w przypadku doboru indywidualnego, takie cechy rozmnażającego się osobnika, które zapewniają największy sukces reprodukcyjny rozmnażającemu się osobnikowi. W przypadku pokrewieństw między osobnikami faworyzowane mogą być jednak również cechy mające korzystny wpływ na sukces reprodukcyjny osobników spokrewnionych, gdyż są one nosicielami kopii tych samych genów. Ponieważ stopnie pokrewieństwa mogą być różne, to także różne może być nasilenie doboru krewniaczego.

\section{Przykłady doboru krewniaczego}

Przykłady pozwolą zrozumieć, jakie zachowania osobników będą promowane przez dobór krewniaczy. W stadzie lwów samice i samce są ze sobą spokrewnione (Grinnell et al. 1995). Przywódcą stada jest doświadczony samiec, który utrzymuje harem. Samice tworzące harem to siostry. Cieszą się one dużym sukcesem reprodukcyjnym, co zapewnia im między innymi wspólna opieka nad potomstwem. Czas porodu samic jest zbliżony, więc potomstwo jest w podobnym wieku. Dzięki temu samice mogą wzajemnie karmić potomstwo wtedy, gdy inne wyruszają na polowanie. Młody samiec, syn przywódcy stada, aby nie konkurować z ojcem, musi opuścić stado. Towarzyszą mu 2-3 młode samce, zwykle bracia. Są oni pomocni w przejęciu miejsca przywódcy w obcym stadzie. Jeden z samców podejmuje walkę z przywódcą tego stada, a reszta pomaga mu (Packer and Pusey 1982). Po udanej walce zakończonej sukcesem dla jednego z braci pozostałe samce odchodzą i powtarzają ten schemat w innym miejscu. Zazwyczaj nowy przywódca zabija małe lwiątka 
w nowym stadzie, w celu wyeliminowania genów poprzednika (Bertram 1983).

Susły Beldinga (Spermophilus beldingi) są gryzoniami zamieszkującymi łąki Stanów Zjednoczonych Ameryki. Zaraz po okresie godowym samiec opuszcza norę gniazdową, pozostawiając samicę z potomstwem. Spędza ona większość czasu w otoczeniu bliskich krewniaczek znajdujących się w takiej samej jak ona sytuacji. Współpracuje z nimi w wychowaniu i obronie potomstwa. W momencie zbliżania się zagrożenia samice wydają okrzyki alarmowe. Osobnik ostrzegający zwraca na siebie uwagę agresora i ponosi koszt swojego czynu, dając tym samym możliwość ucieczki pozostałym osobnikom. Sherman (1977) stwierdził, że samice znajdujące się w gronie bliskich krewnych dużo częściej wydawały sygnały ostrzegawcze w celu ochrony swoich bliskich niż w przypadku przebywania z niespokrewnionymi osobnikami. Warto również wspomnieć, iż okrzyki alarmowe są wydawane nie tylko przez samice-matki, lecz także przez nieposiadające jeszcze potomstwa młode samice.

Innym przykładem pokazującym współpracę osobników spokrewnionych jest kokoszka tasmańska (Tribonyx mortierii). W przypadku tego nielotnego ptaka zamieszkującego Tasmanię samce i samice łączą się w pary bądź trójki. Powodem tego jest mniejsza liczba samic niż samców. Powstają więc rodziny składające się z samicy i dwóch samców. Ważne jest to, że są to bracia. Oba samce biorą udział w wychowaniu potomstwa. Jeden z nich zawsze jest jednak osobnikiem dominującym, który mimo to pozwala swojemu bratu na kopulację z samicą. Pokrewieństwo powoduje, że samce współpracują ze sobą, a obecność dominującego samca w tym układzie gwarantuje to, że nie dochodzi między nimi do konfliktów. Współpraca znacznie zwiększa szanse na sukces rozrodczy rodziny, gdyż liczba wyprowadzonego z gniazda potomstwa jest większa w przypadku trójki niż pary rodziców (Krebs and Davies 2001).

Warto zwrócić uwagę na trzy sprawy. Po pierwsze, z powyższych przykładów widać, że dobór krewniaczy popiera zachowania, które noszą znamiona współpracy, a w niektórych przypadkach, jak się wkrótce przekonamy, także altruizmu. Po drugie widać, że współpraca i zachowania altruistyczne pojawiają się między osobnikami spokrewnionymi. Po trzecie, powyższe przykłady dotyczą osobników na tyle inteligentnych, że są w stanie rozpoznawać, kto jest ich krewnym, a kto nie. Jednakże, jak się wkrótce przekonamy, współpracę między krewnymi obserwować możemy również u organizmów, które trudno posądzić o to, że mają inteligencję podobną do tej, jaką posiadamy my - ssaki. Współpraca widoczna jest również między osobnikami niespokrewnionymi tego samego gatunku.

\section{Rozpoznawanie krewnych}

Jeśli osobnik zachowuje się inaczej w stosunku do osobników z nim spokrewnionych niż w stosunku do osobników niespokrewnionych, to musi w jakiś sposób rozpoznawać swoich krewnych. Można traktować jako krewnych tych, z którymi się wspólnie dorastało w tym samym gnieździe (Holmes and Sherman 1982). Osobniki niektórych gatunków potrafią całkowicie zignorować swoją rodzinę, jeżeli zostaną odpowiednio wcześnie przeniesione w inne miejsce niż to, w którym się urodziły. Za to bez większego trudu traktują obcą rodzinę w nowym miejscu jak własną. Bardzo dobrym przykładem jest naśladownictwo, które ma miejsce na przykład u gęsi. Po wykluciu pisklęta podążają za pierwszym dostrzeżonym osobnikiem - najczęściej krewnym. Tak więc wczesne doświadczenia niektórych zwierząt są bezpośrednio powiązane z krewnymi i jednocześnie mają wpływ na ich zachowanie jako dojrzałych osobników.

Mniej prawdopodobną koncepcją rozpoznawania krewnych, która została sformułowana przez Richarda Dawkinsa, a stworzona pierwotnie przez Williama Hamiltona, jest "efekt zielonej brody" (Krebs and Davies 2001). Zakłada ona, że osobniki posiadające tę samą cechę, czyli umowny allel „zielonej brody", są w stanie rozpoznać inne osobniki 
posiadające tę cechę i nakłonić je do zachowań altruistycznych, samemu zachowując się również w podobny sposób.

Istnieją dowody, że genetycznie spokrewnione osobniki, które nie wychowały się razem, są w stanie zachowywać się mniej agresywnie w stosunku do siebie. Ma to jednak miejsce tylko w odniesieniu do samic. Być może powodem jest tendencja do szybkiego opuszczania miejsca urodzenia i niepozostawania w otoczeniu krewnych, jaką obserwujemy zwykle u samców. To raczej samice spędzają większość życia z mniej lub bardziej spokrewnionymi z nimi samicami. Badania Paula Shermana (Sherman 1977) przeprowadzone na samicach susła Beldinga pokazują, że samice, które są w pełni ze sobą spokrewnione, są bardziej skłonne do pomocy i współpracy. Zjawisko to nie miało miejsca, jeżeli w pobliżu pojawiły się przyrodnie siostry. Nasilenie agresji w stosunku do sióstr przyrodnich nie było widoczne, jeśli umieszczono w tej samej norze $\mathrm{w}$ pełni ze sobą spokrewnione samice i siostry przyrodnie. Można więc podejrzewać, że być może jedna wspólna cecha występująca u wszystkich sióstr, na przykład zapach lub wspólna nora, pozwala już na rozpoznawanie krewnych, jednakże połączenie pokrewieństwa i wspólnego wychowania znacznie wzmaga możliwość rozpoznawania krewnego (Holmes and Sherman 1982). Z drugiej strony wspólne wychowanie może być tak silną sugestią, że osobnik, z którym się wychowujemy, jest "automatycznie" naszym bliskim krewnym, iż nie rozpatrujemy innych sygnałów, które świadczą o pokrewieństwie. Chociaż wydaje się również, że w przypadku braku wspólnego wychowania znacznie łatwiej jest rozpoznać rodzeństwo w pełni spokrewnione niż przyrodnie, kierując się wyłącznie sygnałem pokrewieństwa, a nie wspólnym wychowaniem.

\section{Altruizm}

W zachowaniach altruistycznych biorą udział dwie strony. Jest dawca altruizmu nazwiemy go altruistą - i odbiorca korzyści wynikających z tego zachowania. Altruista nie ma żadnych korzyści ze swojego zachowania. Ponosi wyłącznie straty. Korzyści ma odbiorca altruizmu. Ponieważ obracamy się w kręgu biologii, to straty i korzyści mierzymy w obniżeniu lub zwiększeniu sukcesu reprodukcyjnego stron biorących udział w zachowaniu altruistycznym.

Altruistyczne jest zachowanie rodziców w stosunku do swego potomstwa, zwłaszcza w pierwszym okresie opieki nad nim. Bardziej złożone są przyczyny altruizmu u owadów społecznych. W tym ostatnim przypadku mamy do czynienia z poświęcaniem życia (np. kasta żołnierzy) w obronie gniazda czy też brak uczestnictwa w reprodukcji (np. robotnice) na rzecz sukcesu reprodukcyjnego królowej matki. Osobliwym przykładem altruizmu jest opuszczanie gniazda przez chore lub zranione robotnice niektórych mrówek, które nie mogą już spełniać swoich funkcji, natomiast mogłyby stanowić pewne zagrożenie dla owadziej społeczności.

\section{Reguła Hamiltona}

William D. Hamilton, twórca teorii doboru krewniaczego, sformułował prostą regułę przewidującą, kiedy dobór krewniaczy będzie faworyzował akty altruizmu. Hamilton zaproponował porównać koszty $C$ zachowania altruistycznego ponoszone przez altruistę z korzyściami $B$ tego zachowania dla odbiorcy altruizmu. Zachowanie altruistyczne będzie promowane przez dobór krewniaczy, gdy:

$$
\frac{B}{C}>\frac{1}{r}
$$

gdzie $r$ jest współczynnikiem pokrewieństwa pomiędzy osobnikami biorącymi udział w tym zachowaniu.

Powyższa reguła posłużyła do wyjaśnienia przejawów altruizmu u owadów społecznych - mrówek, pszczół i termitów zwanych również owadami eusocjalnymi (Woyciechowski 2009). Charakteryzują się one trzema cechami (Krebs and Davies 2001): 1) ma miejsce wspólna opieka nad potomstwem, która obejmuje wszystkie młode osobniki żyjące w gnieździe; 2) występują 
bezpłodne kasty, które wychowują młodsze rodzeństwo, zamiast posiadania i wychowania własnego potomstwa; 3) mamy do czynienia z zachodzącymi pokoleniami, w tym samym gnieździe żyje równocześnie matka oraz jej dorosłe i młodsze potomstwo.

Struktura gniazda owadów eusocjalnych wygląda następująco. Na czele gniazda stoi samica zwana królową. Jako jedyna w gnieździe rozmnaża się. Pozostałe samice są córkami królowej i pełnią rolę robotnic. „Zrezygnowały” one z posiadania własnego potomstwa na rzecz wychowania swoich młodszych sióstr i braci, czyli innych córek i synów królowej. Robotnice mają określone zadania w gnieździe, które zależą od ich wieku. Są to kasty wyspecjalizowane w wykonywaniu określonego zakresu obowiązków. Część zajmuje się opieką nad młodszym rodzeństwem, inna kasta zajmuje się obroną gniazda, a kolejna zdobywaniem i dostarczaniem pokarmu. Trzeba pamiętać, że oprócz samic w gnieździe żyją również samce, lecz po odchowaniu są zmuszane do opuszczenia gniazda.

Sterylność robotnic u owadów eusocjalnych wynika ze specyfiki ich systemu rozrodczego. Samice są diploidalne, a samce haploidalne. Królowa kopuluje tylko z jednym samcem, przechowuje jego plemniki w swoim ciele przez całe życie i używa ich do zapłodnienia składanych jaj. Haploidalny samiec rozwija się z niezapłodnionego jaja, natomiast samica rozwija się z zapłodnionego jaja, więc jest diploidalna. Taki układ genetyczny prowadzi do nietypowych pokrewieństw między osobnikami zamieszkującymi gniazdo (Gillooly et al. 2010).

Wykorzystując przedstawioną wyżej regułę Hamiltona, można obliczyć wartość współczynnika pokrewieństwa pomiędzy siostrami - robotnicami. Równa się on 0,75. Ten sam współczynnik dla królowej i jej córek oraz synów jest równy o,5. Współczynnik pokrewieństwa robotnic z braćmi wynosi już tylko o,25. Natomiast gdyby robotnice miały potomstwo, to wtedy współczynnik pokrewieństwa byłby równy o,5. Wynika z tego, że robotnice są ze sobą bardziej spokrewnione niż ze swoim potencjalnym potomstwem.

Sieć pokrewieństw między mieszkańcami gniazda reguluje jego strukturę społeczną. W interesie królowej jest, aby u jej potomstwa proporcja płci była 1:1, gdyż królowa jest tak samo spokrewniona ze swoimi diploidalnymi córkami i haploidalnymi synami. Ale nie jest to zgodne $\mathrm{z}$ interesem robotnic, ponieważ współczynnik pokrewieństwa pomiędzy siostrami jest znacznie większy niż między siostrami i braćmi. Nie ma więc genetycznie uwarunkowanego powodu, aby poświęciły się i opiekowały swoim młodszymi braćmi tak samo intensywnie jak siostrami. W większości przypadków konflikt między królową i robotnicami na tym tle wygrywają robotnice, gdyż to one wykonują wszystkie prace związane z utrzymaniem gniazda. Robotnice mają zatem możliwość kontroli struktury gniazda i w tym celu posuwają się nawet do uśmiercania odpowiedniej liczby swoich braci. W ten sposób, poprzez utrzymanie odpowiedniej dla robotnic proporcji samców do samic w gnieździe, możliwe jest prawidłowe funkcjonowanie tego społeczeństwa, ale zgodnie z interesami robotnic.

Zdarza się jednak, że królowa w czasie godów kopuluje z więcej niż jednym samcem. W takim przypadku struktura gniazda może się bardzo skomplikować, ponieważ współczynnik pokrewieństwa pomiędzy robotnicami nie jest już jednakowy. Ma to jednak swoje plusy i minusy. Z jednej strony grozi to rozpadem społeczeństwa, z drugiej zapewnia różnorodność genetyczną robotnic, co potencjalnie może chronić gniazdo przed pasożytami.

Przykład os z gatunku Polistes metricus pokazuje, że zdarza się, iż to królowa odnosi zwycięstwo w konflikcie ze swoimi córkami. Królowa produkuje młode samce na początku sezonu, co eliminuje możliwość kontrolowania proporcji składanych jaj przez robotnice, ponieważ niewiele $\mathrm{z}$ nich pojawia się do tego czasu. Nieliczne, które zdążyły to zrobić, są całkowicie kontrolowane przez królową. Można zatem dojść do wniosku, 
że rezultat konfliktu królowa-robotnice jest uzależniony od bardzo drobnych szczegółów historii życia osobników, które wpływają na to, czy w gnieździe rządzi królowa, czy robotnice.

Osobniki większości gatunków owadów prowadzą samotniczy tryb życia. W przypadku owadów eusocjalnych ma miejsce rzadko spotykane zjawisko, kiedy samica jest w stanie wytworzyć potomstwo zarówno z zapłodnionego, jak i niezapłodnionego jaja. Owady społeczne odnoszą ogromny sukces ekologiczny w bardzo różnych środowiskach. Nie spotkamy ich właściwie tylko na terenach okołobiegunowych. Dzięki altruizmowi i współpracy te małe organizmy przekształcają w znaczący sposób środowisko, w którym występują. Posiadają również wiele zadziwiających umiejętności. Uprawiaja grzyby oraz hoduja mszyce w swoich gniazdach. Nie bez przyczyny biolodzy używają pojęcia „superorganizm” w odniesieniu do gniazda owadów społecznych, w którym poszczególne osobniki są traktowane jako części jednej, większej całości (Wohlleben 2017).

\section{Eusocjalna organizacja społeczeństw u ssaków}

Istnieje gatunek ssaków funkcjonujący i tworzący strukturę społeczną podobną do owadów eusocjalnych. Afrykańskie golce (Heterocephalus glaber) żyjące na pustynnych obszarach Afryki Wschodniej są gatunkiem małych ssaków. Zarówno samice, jak i samce są diploidalne. Obie płcie pochodzą $\mathrm{z}$ rozrodu płciowego i rozwijają się z zapłodnionych jaj. Podobnie jednak jak w przypadku owadów społecznych mamy u golców królową, która jako jedyna może się rozmnażać, oraz podział na kasty wśród jej potomstwa. W stadzie mamy zarówno robotnice, jak i robotników, a ich rolą jest między innymi opieka nad młodszym rodzeństwem. $\mathrm{Na}$ ten stan rzeczy pokrewieństwo nie ma jednak wpływu. Struktura gniazda - taka sama jak w przypadku owadów eusocjalnych - utrzymuje się, ponieważ córki królowej są poniekąd zmuszone przez nią do nieposiadania własnego potomstwa. Królowa wydziela bowiem inhibitor, $\mathrm{z}$ powodu którego inne samice nie są w stanie osiągnąć dojrzałości płciowej i w konsekwencji nie mogą posiadać własnego potomstwa (Brett 1986).

\section{Dobór grupowy}

Większość znanych przykładów działania doboru i adaptacji związanych jest z korzyściami, jakie płyną dla osobników. Dobór promujący adaptacje korzystne dla osobników nazywamy doborem indywidualnym. Sztandarowym przykładem efektów takiego doboru jest melanizm przemysłowy u motyla Biston betularia. Dorosłe osobniki tego gatunku przesiadują na pniach drzew. Zanim w Wielkiej Brytanii rozpoczęła się era przemysłowa i atmosfera zaczęła być zanieczyszczana pyłami emitowanymi z fabrycznych kominów, pnie drzew były stosunkowo jasne. Wśród osobników Biston betularia przeważała forma biała, niewidoczna na tle jasnego pnia dla polujących na nie ptaków. Ciemna forma motyla była w tamtych czasach rzadkością. Pokryte jednak pyłami przemysłowymi pnie drzew stały się ciemne i jasna forma motyla zaczęła być zagrożona. Od tego czasu obserwuje się ogromny wzrost udziału ciemnych form Biston betularia niewidocznych na tle również ciemnych pni.

Okazuje się, że wiele adaptacji u osobników, które są wynikiem doboru indywidualnego i które tym osobnikom przynoszą korzyści, jest także dobrych dla grupy innych osobników spokrewnionych i niespokrewnionych. Na przykład umiejętność polowania w grupie czy ostrzeganie przed drapieżnikiem. To, że są one także dobre dla grupy osobników, jest produktem ubocznym ich pierwotnych funkcji dających korzyści osobnikom. Najbardziej jednak interesujące adaptacje z tej kategorii to takie, które są niekorzystne dla osobnika, ale korzystne dla grupy niespokrewnionych osobników. Dobór, który prowadzi do powstawania takich adaptacji, nazywamy doborem grupowym. 
Zwolennikiem doboru grupowego był brytyjski biolog Vero C. Wynne-Edwards, który w 1962 r. zaproponował dla wyjaśnienia tego, dlaczego ptaki ograniczają reprodukcję, hipotezę utrzymaną w takim właśnie duchu (Wynne-Edwards 1962). Argumentował on, że dzieje się tak dlatego, żeby populacja ptasia nie była zbyt przegęszczona. Była to właściwie pierwsza świadoma prezentacja argumentów ewolucyjnych w kategoriach doboru grupowego. Problem ten pojawił się jako konsekwencja eksperymentów, w których manipulowano lęgami ptaków. Podkładano ptakom do gniazda dodatkowe jaja i okazywało się, że ptaki były w stanie z sukcesem wyprowadzić z gniazda sztucznie zwiększony lęg. Istnieje jednak alternatywne wyjaśnienie tego zjawiska utrzymane w duchu doboru indywidualnego. Zaprezentował je inny brytyjski biolog David Lack (1954; 1966). Otóż ptaki ograniczają reprodukcje w sezonie lęgowym dlatego, aby optymalnie rozłożyć wysiłek reprodukcyjny na wszystkie sezony rozrodcze i w rezultacie tego uzyskać maksymalny sukces reprodukcyjny w skali całego życia.

Obecnie właściwie każdemu wyjaśnieniu zjawisk biologicznych w duchu doboru grupowego potrafimy przeciwstawić wyjaśnienie w kategorii doboru indywidualnego. Przytoczmy przykład podany przez Richarda Dawkinsa (1976). Do stada pasących się na sawannie antylop podkrada się drapieżnik. Nagle jedna z antylop zaczyna podskakiwać. Dlaczego to robi? Wyjaśnienie w kategoriach doboru grupowego: ostrzega inne antylopy, więc robi coś dobrego dla grupy antylop, ale jednocześnie szkodzi sobie, gdyż zwraca uwagę drapieżnika na siebie. Wyjaśnienie w kategoriach doboru indywidualnego: pokazuje drapieżnikowi, jaka jest silna, i sugeruje mu, nie goń mnie, tylko moje koleżanki. Jakie wyjaśnienie wybrać? Powinniśmy kierować się w tym przypadku dodatkowymi względami. Zwykle wyjaśnienia w kategoriach doboru indywidualnego są prostsze i odwołują się do dobrze zdefiniowanych cech osobnika. Jeśli odwołamy się do argumentów z kategorii doboru grupowego, to musimy uznać, że grupa osobników może posiadać cechy, jakie zwykle przypisujemy osobnikom. Osobniki jednak powstają, reprodukują się i umierają częściej niż grupy osobników. Więcej jest zmienności genetycznej między osobnikami niż między grupami osobników. Silniejsze także są korelacje między cechami osobnika a jego reprodukcją, niż między cechami grupy a jej zdolnością do tworzenia potomnych grup.

Z powyższych powodów obecnie uważa się, że dobór grupowy albo w ogóle nie działa, albo jest znacznie słabszy od doboru indywidualnego. W przeciwieństwie do „egoistycznego" doboru indywidualnego dobór grupowy powoduje powstawanie "szlachetnych" adaptacji. Zachowania będące przejawami altruizmu, pomocy innym osobnikom grupy będą promowane przez dobór grupowy. Grupa na tym oczywiście bardzo zyskuje. Problem polega jednak na tym, że takie szlachetne zachowania nie są odporne na pojawienie się osobnika zachowującego się egoistycznie. Taki egoista będzie wykorzystywał szlachetność innych, a sam nie będzie grupie dawał niczego. Ponieważ obracamy się w sferze biologii, w której jakość osobnika mierzy się liczbą jego potomstwa, to egoista odniesie większy reprodukcyjny sukces. W ciągu paru pokoleń z grupy wyparte zostanie potomstwo szlachetnych osobników i zastąpione potomstwem egoistów.

Działania doboru grupowego możemy spodziewać się w niewielkich, izolowanych populacjach. To są warunki, w jakich żyją wewnętrzne pasożyty - organizmy zasiedlające wnętrze ciała większych zwierząt. Albo pod wpływem działania doboru grupowego, albo bez jego udziału, a jedynie w wyniku przypadkowego zdarzenia, szczególnie silnie wpływającego na małe populacje, mogą zostać one zdominowane przez altruistyczne formy pasożytów. Będzie się to przejawiać ich mniejszą zjadliwością - ograniczą wyrządzane gospodarzowi szkody, aby zostawić więcej dla następnych pokoleń. Tym tłumaczy się spadek liczby zachorowań u ludzi na choroby zakaźne, jak również łagodniejszy 
ich przebieg w stabilnych warunkach socjalnych i historycznych oraz gwałtownie wybuchające epidemie tych chorób w okresach wojen, gdy masy ludzkie przemieszczają się i intensywnie kontaktują się ze sobą.

\section{Współpraca między osobnikami niespokrewnionymi}

Dotychczasowe omówienie pokazuje, że współpraca i altruizm między osobnikami spokrewnionymi występuje w przyrodzie. Skoro możliwości udziału doboru grupowego w kształtowaniu takich adaptacji zostały, jak to wynika z poprzedniego rozdziału, wykluczone albo mocno ograniczone, to nasuwa się pytanie, czy jest również możliwa współpraca pomiędzy osobnikami niespokrewnionymi tego samego gatunku, która byłaby produktem doboru indywidualnego (Clutton-Brok 2009). Istnieją przykłady i ich ewolucyjne wyjaśnienia pozwalające twierdząco odpowiedzieć na to pytanie.

Przykładem takiej współpracy mogą być nietoperze wampiry (Desmodus rotundus), które są ssakami z podrodziny liścionosowatych odżywiającymi się krwią innych zwierząt. Zdobytą krew mogą zostawić dla siebie, bądź podzielić się nią z niespokrewnionym nietoperzem. Często zdarza się, że nietoperze zwracają część krwi i oddają ją osobnikowi, od którego w przeszłości otrzymały ten sam rodzaj pomocy. Suma korzyści w dłuższej perspektywie czasu jest prawdopodobnie większa od kosztów (Carter and Wilkinson 2013).

Podobne zjawisko można również zaobserwować u naczelnych. Przymierza oparte na wzajemności są zawierane w celu obrony przed innymi osobnikami z własnego gatunku lub ze względu na możliwość zdobycia samicy. Takim przykładem mogą być pawiany Anubis (Papio anubis). Samica wybiera samca na podstawie pewnego rodzaju turnieju zapaśniczego - samce walczą ze sobą na oczach samicy. Samiec może poprosić innego, niespokrewnionego samca o pomoc. Wciąga w walkę samca pomocnika, a ten ostatni celowo przegrywa walkę, po której dochodzi do kopulacji zwycięzcy z samicą. Ma tu miejsce manipulacja samicą dokonana przez dwóch samców. Jeden z nich od początku wie, że musi przegrać walkę o samicę. Z czasem ich role się odwracają. Samiec, któremu została udzielona pomoc w przeszłości, odwdzięcza się w przyszłości tym samym swojemu pomocnikowi (Parker 1977).

Innym przykładem jest wzajemne iskanie małp. Jest to zachowanie funkcjonujące również dzięki wzajemności. Osobnik uważany za pomocnego przy iskaniu, gdyż w przeszłości chętnie pomagał innym w usuwaniu pasożytów, znalazłszy się w potrzebie, może liczyć na wsparcie ze strony innych. Badania potwierdzają, że w przypadku osobników niespokrewnionych małpy częściej reagują na zachętę do iskania od osobników, które w przeszłości uczyniły to samo względem nich.

\section{Altruizm odwzajemniony}

Współpraca, która polega na wzajemnej korzyści zarówno pomiędzy osobnikami spokrewnionymi, jak i niespokrewnionymi, w większości przypadków jest opłacalna. W 1971 r. etolog Robert Trivers sformułował pojęcie altruizmu odwzajemnionego (Trivers 1971).

Altruizm odwzajemniony polega na dokonywaniu aktów altruizmu wtedy, gdy altruista oczekuje, że w przyszłości osobnik, który otrzymał pomoc, będzie w stanie się "odwdzięczyć". Przykładów takich relacji dostarczają nie tylko przedstawiciele naczelnych. Badania przeprowadzone przez Rutte i Tabrosky'ego (2008) pokazują, że altruizm odwzajemniony występuje u niektórych gatunków szczurów. Szczury wędrowne (Rattus norvegicus) zostały umieszczone w klatkach zawierających „patyk”, który był dla nich przeszkodą w dostaniu się do pożywienia. Szczury nauczyły się ją usuwać, aby uzyskać dostęp do jedzenia. Szczur wciągał patyk nie tylko dla siebie, lecz także dla innego szczura tak, aby ten również mógł się pożywić. Gdy role się odwracały, szczur, który wcześniej otrzymał w ten sposób 
pożywienie, umożliwił dostęp do jedzenia swojemu dobroczyńcy.

Altruizm odwzajemniony jest możliwy, mimo że można oczekiwać, iż zawsze będą w populacji istnieli oszuści. Zdarza się tak, że osobnik cały czas daje coś od siebie, a inny korzysta z tego, nie dając nic w zamian. Możemy to uznać za akt manipulacji altruistami. Przykładem takiej sytuacji jest zachowanie kukułek. Niektóre samice w celu uniknięcia kosztów opieki rodzicielskiej składają jaja w gniazdach innych osobników tego gatunku. To zachowanie jest oszustwem oraz manipulacją inną samicą, która potem ponosi koszty związane z wysiadywaniem jaj i opieką nad nieswoim potomstwem (Krebs and Davies 2001). Można zatem zadać pytanie, dlaczego to nieuczciwe zachowanie utrzymuje się w populacji. Zwykle tylko niewielki procent osobników dopuszcza się oszustwa. Gdyby większość osobników oszukiwała, przejawy altruizmu odwzajemnionego nie mogłyby się w populacji utrzymać. Oszuści są wyjątkami i stanowią mniejszość. Większość osobników z reguły nie oszukuje, a preferuje współpracę z innymi osobnikami, odwzajemniając ich altruistyczne zachowania.

\section{Dylemat więźnia}

Problem zwany dylematem więźnia sformułowany przez Roberta Axelroda i Williama D. Hamiltona w 1981 r. ma na celu wyjaśnienie tego, jak nawiązać współpracę $\mathrm{z}$ osobnikiem niespokrewnionym (Axelrod and Hamilton 1981). Załóżmy, że w celi zostali osadzeni dwaj więźniowie. Każdy z nich chciałby skrócić pobyt w zamknięciu. Jedyną możliwością ucieczki jest wykopanie podkopu. Czy bezpieczne jest zatem zaproponowanie współwięźniowi wspólnego wykopania podkopu. Czy będzie on chciał współpracować? A może lepiej w tej sytuacji wykonać podkop samemu? Bez wątpienia współpraca się opłaca. Współwięzień jednak może zdecydować, że korzystniejsze jest dla niego niewspółdziałanie, lecz doniesienie dyrekcji więzienia o zamiarze ucieczki i liczenie na złagodzenie kary. Rozwiązaniem dylematu więźnia jest wynik gry zwanej wet za wet. Najlepsze strategie w niej zależą od tego, czy osobniki spotykają się i grają ze sobą jednorazowo czy wiele razy. W pierwszym przypadku najlepszą strategią jest brak współpracy, ponieważ nie zwróci się nakład pracy włożony we współpracę. Natomiast gdy osobniki mają szansę grać ze sobą wiele razy, to najlepsza strategia polega na oferowaniu współpracy przy pierwszym spotkaniu. Gdy partner przyjmuje ofertę, osobniki powinny współpracować. Gdy partner nie podejmuje współpracy, nie należy mu oferować jej w przyszłości (Marshall 2009; Zentall 2016).

\section{Współpraca jako wynik doboru płciowego}

Współpraca między osobnikami niespokrewnionymi może być również wynikiem działania doboru płciowego. Przykłady można wskazać u ptaków i nietoperzy (Wilkinson 1984). Dla samicy niezwykle ważny jest wybór odpowiedniego partnera do rozrodu. Dlatego samice poszukują samców z tak zwanymi „najlepszymi genami”, czyli gwarantującymi samicom sukces reprodukcyjny. W praktyce oznacza to, że potomstwo, które otrzymało „najlepsze geny”, lepiej poradzi sobie w przyszłości ze wszystkimi życiowymi problemami. Samce więc muszą pokazać samicom, że są nosicielami takich właśnie dobrych genów. Przy wyborze partnera samice chętnie zauważają nietypowe zachowania samców, będące efektem doboru płciowego, a które mają sygnalizować samicy, że samiec jest nosicielem „dobrych genów”. Niektóre samce dzielą się na przykład pokarmem z innymi, niespokrewnionymi samcami. To sygnał wysyłany do samicy, że samiec zachowujący się altruistycznie względem konkurentów jest tak dobrym osobnikiem, że nie przeszkadza mu fakt oddania części pokarmu (Krebs and Davies 1978). I tak poradzi on sobie w życiu, dlatego powinien być wybrany przez samicę na ojca jej dzieci. 


\section{Interakcje międzygatunkowe}

Do tej pory rozpatrywane były relacje między osobnikami tego samego gatunku. W tym przypadku bardzo wiele zależy od stopnia pokrewieństwa między osobnikami. Pewne specjalne systemy pokrewieństw umożliwiają ewolucję altruizmu, choć najczęściej będzie to współpraca między krewniakami. Jak jednak pokazują badania wsparte ewolucyjnymi uzasadnieniami, współpraca między osobnikami może się pojawić nawet wtedy, gdy osobniki - mimo że reprezentują ten sam gatunek - nie są ze sobą spokrewnione. Tym niemniej ogromna część relacji każdego osobnika z innymi żywymi istotami to kontakty z przedstawicielami innych gatunków. Osobniki różnych gatunków nie są ze sobą spokrewnione, więc dobór krewniaczy nie może kształtować relacji między nimi.

\section{Relacje międzygatunkowe - tworzenie nisz ekologicznych}

Relacje międzygatunkowe często sprowadzają się do konkurencji i drapieżnictwa. W przypadku konkurencji mimo tego, że najczęściej jeden gatunek jest lepszym konkurentem i wychodzi z tej relacji jako zwycięzca, to jednak w jej wyniku obaj konkurenci tracą. W przypadku układu drapieżnik-ofiara jeden z gatunków zyskuje, a drugi traci. Trudno jednak tego, który traci, nazwać altruistą, gdyż, gdyby mógł, chętnie uniknąłby losu ofiary. Relacje symbiotyczne występują na przykład pomiędzy sprzątaczami a ich gospodarzami. Do osobników, które sprzątają, zaliczamy na przykład krewetki. Natomiast rolę gospodarza przyjmują ryby, żółwie czy też ośmiornice. Gospodarz umożliwia osobnikowi sprzątającemu bezpieczne wyczyszczenie swojego ciała. Przebywanie w pobliżu gospodarza oddala od sprzątacza zagrożenia i ułatwia dostęp do pożywienia. Dla gospodarza czyszczenie jest niezbędne, ponieważ usuwa pasożyty. Istotą tej relacji jest tworzenie nisz ekologicznych dla obu gatunków (Grutter 2002).

Podobne związki między gatunkami spotykamy nie tylko w świecie zwierząt morskich, lecz także lądowych. Przykładem może być afrykański czarny nosorożec (Diceros bicornis) i bąkojad (Buphagus erythrorhynchus), czyli niewielki ptak, który karmi się pasożytami występującymi na skórze nosorożca (Hunt 2017). Bąkojad przemierza sawannę na grzbiecie nosorożca i dzięki temu ma zapewniony tani transport i łatwo dostępny posiłek. W zamian za to bąkojad usuwa pasożyty ze skóry nosorożca.

Jedną z ciekawszych relacji powyższego typu jest związek między kałamarnicą (Euprymna scolopes) i bakteriami (Vibrio fischeri). Kałamarnice żyją w płytkich wodach i prowadzą nocny tryb życia. Kiedy Księżyc rzuca na powierzchnię wody poświatę, kałamarnica widoczna jest jako ciemna plama na tle oświetlonego dna. Wskazuje to drapieżnikom położenie kałamarnicy. Bakterie (Vibrio fischeri) mają zdolność emitowania światła, aby jednak świecić, potrzebują tlenu. Emitowane światło jest ubocznym efektem ich tlenowego oddychania. Bakterie świecą bardzo słabo, gdy żyją pojedynczo. Mogą jednak tworzyć kolonie i wtedy świecą intensywniej, ale może to stanowić dla nich zagrożenie. Gdy bakterie tworzą kolonie na płaszczu kałamarnicy, nie są narażone na niebezpieczeństwo związane $\mathrm{z}$ emitowaniem światła. Kałamarnica w odpowiedzi na zagrożenie ze strony patogenów (na przykład bakterii Vibrio fischeri) wytwarza w organizmie wysoką zawartość tlenu, która przyczynia się do powstania kwasu podchlorawego. W nadmiernej koncentracji jest on szkodliwy dla bakterii. Sposobem pozbycia się tej substancji jest usunięcie tlenu. Wytwarzając światło, bakterie regulują ilość tlenu i kwasu podchlorawego, tworząc na powierzchni ciała kałamarnicy przyjazne dla siebie środowisko. Natomiast dla kałamarnicy emisja światła jest metodą kamuflażu, w której bakterie wytwarzają światło pasujące do tła, czyli powierzchni oceanu (Boettcher and Ruby 1990).

Innym przykładem mogą być małe, morskie ryby błazenki (np. Amphiprion chrysopterus) i ukwiały (np. Heteractis crispa). Błazenki nie sa wrażliwe na śmiertelnie 
niebezpieczne nematocysty, które pochodzą z macek ukwiału, mają bowiem zdolność do wytwarzania ochronnego śluzu zapobiegającego poparzeniom. Dzięki temu mogą przebywać wśród ukwiałów. Korzystanie z tego rodzaju niszy ekologicznej stanowi dla błazenków ochronę przed drapieżnikami. Glenn Litsios (Litsios et al. 2012) sugeruje, że również ukwiały odnoszą korzyści, gdyż błazenki wydzielają amoniak, który jest wykorzystywany w tkankach anemonu. Dzięki ochronie zapewnionej przez ukwiały długość życia błazenków jest sześciokrotnie większa niż oczekiwana długość życia ryby tego rozmiaru, które nie potrafiły zbudować podobnej relacji z innym gatunkiem.

Rozważmy na koniec relację między kleszczami a bakteriami (Anaplasma phagocytophilum) przenoszonymi przez kleszcze i szkodliwymi dla ssaków, na których kleszcze pasożytują. Dla bakterii kleszcze są środkiem transportu pomagającym im przenosić się między organizmami, na których pasożytuje. Aby układ ten funkcjonował, musi on zabezpieczać interesy bakterii i przynosić korzyści kleszczom. W interesie bakterii jest więc zwiększać szansę na przeżycie i reprodukcję kleszczy tak, aby również one miał zapewniony większy sukces reprodukcyjny i mogły się rozprzestrzeniać. Długie obcowanie kleszczy i bakterii nie tylko wykształciło u kleszczy odporność na bakterie, lecz także bakterie uaktywniają w organizmach kleszczy glikoproteiny oraz białka szoku cieplnego. Dzięki temu kleszcze lepiej przeżywają w niskich temperaturach. Dodatkowo białka szoku cieplnego powodują zwiększenie odporności kleszczy na wysuszenie w wysokich temperaturach (De la Fuente et al. 2016). Niestety sprawność działania powyższego związku stanowi bardzo poważne zagrożenie dla trzeciego elementu w tej ekologicznej układance - dla gatunków, na których pasożytują kleszcze.

\section{Zakończenie}

W poprzednim rozdziale opisane zostały relacje, w których przedstawiciele dwóch różnych gatunków osiągają swoje własne cele. Mimo że osobniki każdego z gatunków mogą osiągnąć swoje cele, żyjąc oddzielnie, gdy wchodzą w relację międzygatunkową, przychodzi im to łatwiej.

Czy można tym relacjom międzygatunkowym przypisać znamiona współpracy, a może także i altruizmu? Współpraca zakłada dążenie do wspólnego celu wspólnymi siłami. Jakie są cele osobników we wcześniejszych przykładach? Bieżące, krótkoterminowe cele są bez wątpienia różne. $\mathrm{Na}$ przykład jeden ma szansę najeść się, a inny pozbyć pasożytów. Nie jest to ten sam cel osiągany wspólnymi siłami. Ale patrząc z perspektywy celu promowanego przez dobór naturalny, czyli sukcesu reprodukcyjnego, cele te są identyczne, choć osiągane na innej drodze. Nie podlegają one wspólnej mierze, ale bez wątpienia są osiągane dzięki zgodnemu wysiłkowi.

Większość związków między gatunkami ma za sobą długą historię mierzoną geologiczną skalą czasu, w czasie której podlegały ewolucji. Czynnikiem wpływającym na ten proces jest obecność drugiego gatunku. Proces taki nazywamy koewolucją, czyli wspólną ewolucją gatunków. Powstaje pytanie, w którą stronę ona zmierza. Czy będzie przebiegać od bardziej antagonistycznych związków do współpracy, a może do altruizmu? Przedstawiona relacja między kleszczami a bakteriami nasuwa przypuszczenie, że może ona doprowadzić do kompromisu. Kleszcze nie są podatne na szkodliwy wpływ bakterii. Pomiędzy przedstawicielami tych gatunków nie dochodzi do nasilenia agresji, lecz do utrwalenia układu, w którym oba odnoszą korzyści. Relacje międzygatunkowe mogą zatem zmierzać do zminimalizowania agresji i do tworzenia „łagodniejszych” interakcji. Jest to ewolucyjnie wypracowana forma współpracy między nimi w takim znaczeniu, w jakim przedstawiona została wcześniej.

Czy relacje takie mogą ewoluować w stronę altruizmu? Przyjrzyjmy się relacji człowieka i psa: temu, jak ona ewoluowała i jak wygląda dziś. Wiemy, że pies towarzyszy człowiekowi od tysiącleci, lecz moment udomowienia psa 
nie jest znany. Prawdopodobnie jest to spowodowane zupełnie innym poziomem relacji człowiek-pies w różnych okresach historii człowieka oraz faktem, że związek ten pojawiał się wielokrotnie w różnych miejscach na świecie. Funkcja psa w ludzkich społecznościach była inna niż zwierząt gospodarczych (drobiu, owiec czy kóz). Psy służyły do tropienia, polowania oraz transportowania zwierzyny łownej. W Polsce takie wykorzystanie psów przypadło na średniowiecze. Z czasem spadek pogłowia zwierzyny leśnej oraz karczowanie lasów spowodowały zmniejszenie liczby psów potrzebnych do „zadań bojowych”. Pojawiła się potrzeba posiadania psów, które mogłyby pilnować stad. Można wnioskować, że pies pełnił w przeszłości funkcję „roboczą”, a oprócz tego pozostawał w bliskim otoczeniu człowieka i był poniekąd jego towarzyszem. Dziś psy w dalszym ciągu mogą służyć do pilnowania domu lub tropienia, ale pojawiła się także ich nowa funkcja: są pomocne w wychowaniu dzieci, lub zapewniają towarzystwo osobom starszym lub samotnym. Są to obecnie najczęstsze powody posiadania psa. Pojawia się pytanie, czy to jedyne powody i czy, decydując się na posiadanie psa, bierzemy pod uwagę tylko jego „funkcjonalność”?

Rozważmy sytuację, kiedy - nie posiadając jeszcze dzieci - decydujemy się na adopcję psa ze schroniska. Na początku traktujemy go jak towarzysza, a z czasem jako członka rodziny. Karmimy, wspólnie spacerujemy, bawimy się i cieszymy z tego, że jest $\mathrm{z}$ nami. Nie wykorzystujemy go jako siły roboczej. Czy jest to bezinteresowne stworzenie więzi, czy niczego nie oczekujemy od psa? Spójrzmy na to od strony psa. Jest karmiony, nabiera zaufania do człowieka. Oczekuje głaskania i chce uczestniczyć we wszystkim, co robią jego „właściciele”. Każdy posiadacz psa na pewno zauważył, jak bardzo pies cieszy się z powrotu właściciela do domu. My, jako ludzie, również odczuwamy radość, widząc szczerą reakcję psa. Czy możemy w tej sytuacji mówić o altruizmie? Sądzimy, że w przypadku relacji człowiek-pies „dług”, jaki pies posiada wobec człowieka, jest obecnie najczęściej spłacany przez niego w formie wdzięczności i lojalności. Intensywność tej spłaty jest tak duża, że zachowanie psa wydaje się nam całkowicie bezinteresowne i znacznie silniejsze, niż może się to zdarzyć między ludźmi (Ellson 2008; Pizarro 2000).

Podobnej relacji, opartej na więzi emocjonalnej, nie jesteśmy w stanie stworzyć z kurami czy krowami. Pies musi więc mieć dużą zdolność do odczuwania emocji. Dodatkowy sposób komunikacji odgrywa bardzo istotną rolę w stworzeniu tej relacji. Psy potrafią pokazać zachowaniem swoje nastroje. System komunikacji człowieka jest podobny. Być może dla człowieka i psa istnieje wspólny repertuar znaków i taki sam sposób ich odbioru. Dla psa człowiek jest naturalnym - choć niekoniecznie identycznym gatunkowo - członkiem sfory i naturalnym partnerem komunikacji (Fleischer 2003). Być może jest to uzasadnienie, dlaczego akurat na kontakt człowieka z psem możemy patrzeć przez pryzmat altruizmu.

Przyjrzyjmy się relacji człowiek-pies od strony sukcesu reprodukcyjnego. Zanim zdecydujemy się na psa, musimy podjąć decyzję, czy adoptujemy psa, który może mieć potomstwo, czy decydujemy się na osobnika wykastrowanego. Zarówno w pierwszym, jak i w drugim przypadku decyzję o sukcesie reprodukcyjnym psa podejmuje człowiek. W przypadku psa dobrowolna decyzja o rezygnacji z przyszłego potomstwa jest niemożliwa. Pies natomiast nie wpływa na decyzje o reprodukcji człowieka, który sam decyduje, czy chce posiadać potomstwo, czy nie. Pies może przyczynić się do sukcesu reprodukcyjnego człowieka w sposób pośredni. Osoby posiadające psa decydują się na potomstwo częściej niż ci, którzy go nie posiadają, a obecność psa znacznie ułatwia wychowanie dzieci. Czy z punktu widzenia sukcesu reprodukcyjnego możemy twierdzić, że jest to tylko manipulacja ze strony człowieka?

Rozważmy teraz relację pomiędzy człowiekiem i koniem. Nie można stwierdzić, czy początkowo występowała w niej jakakolwiek forma altruizmu. Człowiek był myśliwym, 
a koń pożywieniem. Z czasem rola konia ewoluowała i koń był wykorzystywany przez człowieka jako siła robocza. Wróćmy jednak do momentu, w którym człowiek pierwszy raz dosiadł konia, czyli do epoki neolitu. To wówczas pojawili się ludzie nazywani „zaklinaczami koni”. Czy można uznać, że już wtedy był to rodzaj głębszej relacji między koniem a człowiekiem, która ewoluowała $\mathrm{w}$ kierunku altruizmu?

Współcześnie konie w niektórych miejscach wciąż są wykorzystywane jako siła robocza, w innych jako konie wyścigowe. W tych przypadkach nie można mówić o altruizmie, lecz o zwykłej manipulacji ze strony człowieka. Szczególnie źle należy oceniać postawę człowieka wobec koni w czasach, gdy były one angażowane w ludzkie konflikty zbrojne. Rozważmy jednak przykład konia Przewalskiego, który dziś jest jedynym dziko żyjącym przedstawicielem koni. Obecnie są to konie zdziczałe, ale niegdyś były udomowione przez lud Botai z północnego Kazachstanu. Do wymarcia konia Przewalskiego przyczyniły się ówczesne ciężkie zimy i susze. Dzięki reintrodukcji rasa ta ma szansę powrócić w pierwotne obszary swojego bytowania. Obecnie prowadzi się reintrodukcję w parkach narodowych w Mongolii i Chinach. Czy w tym przypadku występuje prawdziwy altruizm ze strony ludzi, którzy otaczają opieką te zwierzęta oraz - w sposób pośredni np. poprzez dokarmianie - przyczyniają się do zwiększenia ich sukcesu reprodukcyjnego? Korzyści dla ludzi z tego zachowania będą widoczne dopiero po wielu pokoleniach, ale w momencie dokonywania aktu pomocy innemu gatunkowi możemy go traktować jako altruizm ze strony ludzi.

Historie związku człowiek-pies i człowiek-koń pokazują, że relacje międzygatunkowe ewoluują. Początkowo w obu przypadkach występowała manipulacja ze strony człowieka. Z czasem przekształciła się ona we współpracę międzygatunkową. W bardzo nielicznych przypadkach (jak adopcja psa bez pobocznych korzyści oraz reintrodukcja konia Przewalskiego) można mówić również o ewolucji w stronę altruizmu międzygatunkowego. Używając terminu „altruizm międzygatunkowy", mamy na myśli relację pomiędzy dwoma osobnikami różnych gatunków, z których jeden jest świadomy swojego altruizmu i robi coś bezinteresownie w danym momencie, a drugi osobnik bez większej świadomości teraz odwdzięcza się w bliższej lub dalszej przyszłości. To, co również jest ważne w altruizmie międzygatunkowym, to uczucia wyższe, które pojawiają się z czasem u osobnika bardziej świadomego. Patrząc na przedstawione przykłady, trudno jest mówić o prawdziwym altruizmie odwzajemnianym równocześnie przez obie strony tej relacji, ponieważ, jak sądzimy, tego typu altruizm może się rozwinąć tylko w przypadku, kiedy oba organizmy mają tego świadomość. Nie możemy również jednoznacznie stwierdzić, czy jest to czysty altruizm, patrząc na przesunięte w czasie „odwdzięczanie się". Tym niemniej wydaje się, że wprowadzenie pojęcia „altruizm międzygatunkowy" jest niezbędne do opisania relacji występujących pomiędzy osobnikami różnych gatunków znanych nam z obserwacji przyrody lub naszego ludzkiego doświadczenia (Charles 2014).

Wszystko to wiąże się także z oceną intencji, jakie przyświecają człowiekowi podejmującemu działania zmierzające do ochrony przyrody. Czy różne formy ochrony przyrody, na przykład ochronna innych gatunków, są aktem altruizmu? Czy są to akty altruizmu, za którymi kryje się próba odkupienia grzechów, jakie człowiek popełniał i popełnia wobec przyrody? Czy działania ochronne podejmowane przez niektórych ludzi w niektórych miejscach są w stanie zrównoważyć szkody czynione przyrodzie przez innych w innych miejscach? A może za ochroną przyrody nie kryją się altruistyczne intencje. Może jest to czysto egoistyczne działanie ludzi, którego prawdziwym celem jest zachowanie gatunku Homo sapiens. 


\section{Bibliografia}

Axelrod, Robert, and Wiliam D. Hamilton. 1981. "The evolution of cooperation.” Science 211: 1390-1396.

Bertram, Brian C.R. 1983. "Cooperation and competition in lions." Nature 302: 356-356.

Boettcher, Katherine J., and Edward G. Ruby. 1990. "Depressed light emission by symbiotic Vibrio fischeri of the sepiolid squid Euprymna scolopes." Journal of Bacteriology 172(7): 3701-3706.

Brett, Robert A. 1986. The ecology and behaviour of the naked mole-rat, Heterocephalus glaber Ruppell (Rodenti: Bathyergidae). Doctoral dissertation. University College, London.

Carter Gerald G., and Gerald S. Wilkinson. 2013. "Food sharing in vampire bats. Reciprocal help predicts donations more than relatedness or harassment." Proceedings of the Royal Society B: Biological Sciences 280(1753): 20122573.

Charles, Nickie. 2014. "Animals just love you as you are: Experiencing kinship across the species barrier." Sociology 48(4): 715-730.

Clutton-Brock, Tim. 2009. "Cooperation between non-kin in animal societies." Nature 462: 51-57.

Dawkins, Richard. 1976. The Selfish Gene. Oxford: Oxford University Press.

De la Fuente, Jose, Margarita Villar, Alejandro Cabezas-Cruz, Agustín Estrada-Pena, Nieves Ayllon, and Pilar Alberdi. 2016. "Tick-host-pathogen interactions: conflict and cooperation." Plos Pathogens 12(4): e1005488.

Ellson Tony. 2008. "Can we live without a dog? Consumption life cycles in dog-owner relationships." Journal of Business Research 61(5): 565-573.

Fleischer, Michael. 2003. Komunikacja międzygatunkowa. Przypadek: człowiek - pies. Dostęp 9.03.2020. http://www.fleischer.pl/text/hunde-art.pdf.

Foster, Kevin R., Tom Wenseleers, and Francis L. Ratnieks. 2006. "Kin selection is the key to altruism." Trends in Ecology and Evolution 21(2): 57-60.

Gillooly, James F., Chou Hou, and Michael Kaspari. 2010. "Eusocial insects as superorganisms: insights from metabolic theory." Communicative and Integrative Biology 3(4): 360-362.

Grinnell, Jon, Craig Packer, and Anne E. Pusey. 1995. "Cooperation in male lions: kinship, reciprocity or mutualism?" Animal Behaviour 49(1): 95-105.

Grutter, Alexandra S. 2002. "Cleaning symbioses from the parasites' perspective." Parasitology 124(7): 65-81.
Hamilton, William D. 1964. "The genetical evolution of social behaviour." Journal of Theoretical Biology 7: 1-16.

Holmes, Warren G., and Paul W. Sherman. 1982. "The ontogeny of kin recognition in two species of ground squirrels." American Zoologist 22(3): 491-517.

Hunt, Richard. 2017. "The Oxpecker and the Rhino." The Positive Effects of Symbiotic Mutualism on Organizational Survival 3.

Krebs, John R., and Nicholas B. Davies. 1978. Behavioural ecology: an evolutionary approach. Oxford: Blackwell Scientific.

Krebs, John R., and Nicholas B. Davies. 2001. Wprowadzenie do ekologii behawioralnej. Warszawa: Wydawnictwo Naukowe PWN.

Kuzdraliński, Adam. 2011. Mutacje. Dostęp 3.01.2020. http://www.e-biotechnologia.pl/Artykuly/mutacje.

Lack, David. 1954. The natural regulation of animal numbers. Oxford: Clarendon Press.

Lack, David. 1966. Population studies of birds. Oxford: Clarendon Press.

Litsios, Glenn, Carrie A. Sims, Rafael O. Wüest, Peter B. Pearman, Niklaus E. Zimmermann, and Nicolas Salamin. 2012. "Mutualism with sea anemones triggered the adaptive radiation of clownfishes." BMC Evolutionary Biology 12(1): 212.

Mackenzie, Aulay, Andy S. Ball, and Sonia R. Virdee. 2015. Ekologia. Krótkie wyktady. Warszawa: Wydawnictwo Naukowe PWN.

Marshall, James A.R. 2009. The donation game with roles played between relatives. Dostęp 1.05.2020. https://hal.archives-ouvertes.fr/hal-00559144/ document.

Packer, Craig, and Anne E. Pusey. 1982. "Cooperation and competition within coalitions of male lions: Kin selection or game theory?" Nature 296: 740-742.

Parker, Craig. 1977. "Reciprocal altruism in Papio Anubis." Nature 265: 441-443.

Pizarro, David. 2000. "Nothing more than feelings? The role of emotions in moral judgment." Journal for the Theory of Social Behaviour 30: 355-375.

Rutte, Claudia, and Michael Taborsky. 2008. "The influence of social experience on cooperative behavior of rats (Rattus norvegicus): Direct vs. generalized reciprocity." Behavioural Ecology and Sociobiology 62: 499-505. 
Sherman, Paul W. 1977. "Nepotism and evolution of alarm calls." Science 197: 1246-1253.

Stearns, Stephen C., and Rolf F. Hoekstra. 2005. Evolution, an introduction. New York: Oxford University Press.

Trivers, Robert. 1971. "The evolution of reciprocal altruism." Quarterly Review of Biology 46: 35-37.

Wilkinson, Gerald. 1984. "Reciprocal food sharing in the Vampire Bat." Nature 308: 181-184.

Wohlleben, Peter. 2017. Duchowe życie zwierzat. Kraków: Otwarte.
Woyciechowski, Michał. 2009. „Dobór krewniaczy a ewolucja owadów eusocjalnych." Kosmos 58(3-4): 347-355.

Wynne-Edwards, Vero C. 1962. Animal dispersion in relation to social behaviour. Edinburg: Oliver and Boyd.

Zentall, Thomas R. 2016. "Reciprocal altruism in rats: Why does it occur?" Learning and Behavior 44(1): 7-8. 